\title{
Peran Aktor Kebijakan Pembatasan Sosial Berskala Besar Dalam Mengatasi Penyebaran COVID-19 Di Indonesia
}

\author{
${ }^{1}$ Diki Suherman \\ ${ }^{1}$ Universitas Padjajaran, Indonesia; dikisuherman44@gmail.com
}

\begin{abstract}
Indonesia is one of the countries affected by COVID-19 (corona virus), Local Distance and Rafid Test (Mass Test) as a step to overcome corona so that it does not spread widely. However, the fact is that positive cases in Indonesia occurred at the beginning of March which increased, on April 5, 2020, positive cases of COVID-19 in Indonesia reached 2,273 cases, 198 died and 164 recovered. The Indonesian government issued a new policy in dealing with the spread of COVID-19 (corona) through the Large-Scale Social Restriction Policy (PSBB) as an effort to break the chain of the spread of this virus which was stipulated in Government Regulation No.21 of 2020 concerning Large-Scale Social Restrictions in the Context of Accelerated Handling of Corona Virus Disease 2019 (COVID-19). The purpose of this journal is to describe the role of large-scale social restrictions (PSBB) policy actors in overcoming the spread of COVID-19 (corona). The method used is qualitative by collecting data using library research sourced from journals, regulations and articles related to policy actors in overcoming COVID-19 (corona) and accountable information media. The results of this journal show that the large role of actors involved in the Large-Scale Social Clearance (PSBB) policy in breaking the chain of the spread of COVID-19 (corona) in Indonesia, this policy can work well when collaboration is built with 5 (five elements) subject or stakeholder elements, namely: Academicians (Academics), Business (Entrepreneurs), Community (society), Government (government) and Media (Mass Media).
\end{abstract}

Keywords: Public Policy, Policy Network, Governance, Healthy Issue, COVID-19

\section{Pendahuluan}

Semua negara di dunia dikejutkan dengan wabah COVID-19 atau yang sering disebut dengan virus corona, wabah ini pertama kali ditemukan di Wuhan, China pada bulan Desember 2019. World Health Organization (WHO) mengatakan bahwa COVID-19 merupakan kasus pandemi, virus ini menular dan menyebar melalui orang ke orang lainnya yang menyebar ke 124 negara. Adapun kasus penyebaran virus ini di China telah mencapai 80.793 orang dengan 14.831 pasien dalam perawatan, 62.7933 pasien dipulangkan sesudah katakan pulih dan 3.169 orang meninggal akibat virus ini. Negara lain yang terkena dampak yang paling banyak akibat virus ini yaitu Italia kasus akibat virus ini naik menjadi 12.462 dari 10.149. Sedangkan sebanyak 9.000 orang terinfeksi virus corona, 2.959 orang dinyatakan pulih. Selain itu Korea Selatan secara keseluruhan kasus yang terjadi menjadi 7.869 orang, 66 korban meninggal. Negara berikut nya adalah Prancis yang mengumumkan 2.281 orang terjangkit virus ini (Redaksi WE Online, 2020).

Setiap negara memiliki cara yang berbeda dalam mengatasi COVID-19 (corona virus) ini, melalui kebijakan yang dilakukan oleh setiap negara, seperti halnya China sebagai negara pertama yang melakukan kebijakan Lock Down kemudian diikuti oleh Italia yang melakukan kebijakan yang sama (Ayu \& Ratriani, 2020). Namun beda halnya dengan Korea Selatan yang tidak melakukan kebijakan tersebut tetapi melakukan kebijakan Social Distancing bagi warga negaranya (Dewi, 2020). 
Indonesia adalah termasuk negara yang terkena COVID-19 (corona virus), untuk mengatasi masalah tersebut indonesia mengikuti langkah seperti yang dilakukan oleh Korea Selatan dengan melakukan Local Distance dan melakukan Rafid Test (Test massal) untuk mengatasi COVID-19 (corona) agar tidak menyebar luas. Namun kenyataannya kasus positif di Indonesia terjadi pada awal bulan maret dan terus meningkat, data terbaru dari covid19.go.id pada 05 April 2020 kasus positif di Indonesia akibat virus ini sebanyak 2.273 kasus, 198 meninggal dan 164 pasien dinyatakan sembuh (Damarjati, 2020).

Berasarkan hal tersebut, maka Pemerintah Indonesia mengeluarkan kebijakan baru dalam mengatasi penyebaran korona yakni "Kebijakan Pembatasan Sosial Berskala Besar (PSBB) sebagai upaya memutus mata rantai penyebaran virus ini yang ditetapkan melalui Peraturan Pemerintah No.21 Tahun 2020 Tentang Pembatasan Sosial Berskala Besar Dalam Rangka Percepatan Penanganan Corona Virus Disease 2019 (COVID-19) (Syamsir et al, 2019). Untuk mengatasi penyebaran COVID-19 ini, tentu tidak bisa hanya dilakukan oleh pemerintah sendiri perlu dilakukan kolaborasi melibatkan semua elemen baik Academician (Akademisi), Business (Pengusaha), Community (mayarakat), Government (pemerintah) dan Media (Media Massa).

Artikel yang ditulis sebelumnya berkenaan dengan COVID-19 (corona) yaitu Kebijakan Pemberlakuan Lockdown sebagai Antisipasi Penyebaran Corona Virus COVID-19 (Yunus \& Annissa, 2020), adapun penelitian lain dari berbagai disiplin ilmu diantaranya di Bidang Ekonomi (Kiky, 2020), Bidang Kesehatan (Rolanda \& Markusb, 2020), Bidang Psikologi (Zulva, 2020), Bidang Kedokteran (Tian, et al, 2020) dan (Parwanto, 2020), BidangAgama (Indriya, 2020), Bidang Politik (Arum, 2020), dan dilihat dari Aturan Perundang-undangan (Telaumbanua, 2020). Penelitian tentang kasus pendemi COVID-19 (corona) masih terhitung baru yakni pendemi yang baru ditemukan dan puncaknya di tahun awal 2020. Teori aktor kebijakan (network actor) Howlett dan Rames (1995) dalam (Yuniningsih, Darmi, 2019), yang dimaksud Penta-helix (Yahya, 2016) adalah kolaborasi 5 (Lima Unsur) unsur subjek atau stakeholder, yaitu: Academician (Akademisi), Business (Pengusaha), Community (mayarakat), Government (pemerintah) dan Media (Media Massa) atau dikenal dengan ABCGM.

Adapun tujuan dari artikel ini yaitu untuk memaparkan peran aktor kebijakan Pembatasan Sosial Berskala Besar (PSBB) dalam mengatasi penyebaran COVID-19 (corona). Permasalah ini perlu diteliti dan dipelajari lanjut karena sangat penting terkhusus bagi Indonesia untuk membuat alternative kebijakan dalam mengatasi penyebaran COVID-19 dengan melibatkan para aktor kebijakan, sehingga mengetahui sejauh mana ketepatan kebijakan tersebut dilakukan dan dampak yang dihasilkan dari kebijakan tersebut.

\section{Metode Penelitian}

Dalam metode penelitian ini, pendekatan yang digunakan adalah kualitatif. Hal ini disebabkan oleh alur penelitian dari umum ke khusus, yang maksudnya adalah bahwa penelitian ini berawal dari hasil pengamatan terhadap fenomena yang ada di lapangan, yang dalam hal ini adalah COVID-19. Kemudian, peneliti berusaha untuk menganalisisnya dengan menggunakan teori dan konsep yang berkaitan dengan fenomena tersebut. Sedangkan jenis penelitian yang digunakan adalah deskriptif, karena peneliti juga ingin menganalisis dan menjelaskan fenomena COVID-19 yang terjadi di Indonesia ini secara lugas dan jelas. Dalam pengumpulan data, teknik yang digunakan adalah studi literatur. Studi literatur ini bersumber dari sejumlah artikel dalam jurnal, buku, peraturan-peraturan, konten media informasi yang berkaitan dengan fokus dan isu penelitian. 


\section{Hasil Dan Pembahasan}

\section{Pelaksanaan Kebijakan Pembatasan Sosial Berskala Besar (PSBB)}

Berdasarkan PP No. 21 Tahun 2010 yang dimaksud Sosial Berskala Besar adalah pembatasan kegiatan tertentu penduduk dalam suatu wilayah yang diduga terinfeksi Corona Virus Disease 2019 (COVID-19) sedemikian rupa untuk mencegah kemungkinan penyebaran Corona Virus Disease 2019 (COVID-19). Melalui persetujuan dari Menteri yang mengatur urusan pemerintahan di bidang kesehatan, dimana Pemerintah Daerah bisa melaksanakan Pembatasan Sosial Berskala Besar atau membatasi pergerakan orang/manusia dan barang di satu Provinsi atau Kabupaten/Kota tertentu, yang didasarkan pada pertimbangan epidemiologis; besarnya ancaman; efektifitas; dukungan sumber daya; teknis operasional; pertimbangan politik; ekonomi; sosial; budaya; pertahanan dan keamanan. Kebijakan ini paling sedikit meliputi peliburan sekolah dan tempat kerja; pemabatasan kegiatan keangamaan; dan atau pembatasan kegiatan di tempat atau fasilitas umum.

Kebijakan ini merupakan respon pemerintah pusat terhadap status kedaruratan kedaruratan masyarakat agar mencegah meluasnya penyebaran penyakit darurat yang terjadi antar orang di satu wilayah tertentu yang disebabkan oleh COVID-19 (corona virus), selain itu sebagai jawaban atas ketidak seragaman antara kebijakan yang dikeluarkan oleh pusat dan daerah. Namun, sebelum kebijakan ini dibuat, daerah melakukan inisaitf tersendiri dalam mengatasi penyebaran COVID-19 (corona) diwilayahnya masing-masing diantaranya adalah Kota Tegal yang memberlakukan local lockdown atau di Indonesia dikenal dengan karantina wilayah, Dedy Yon Supriyono sebagai Wali Kota memberlakukan local lockdown dengan melakukan penutupan akses masuk ke daerahnya selama 4 bulan, yang diberlakukan pada hari Senin 30 Maret 2020 hingga Jumat 30 Juli 2020. Pemerintah Kota Tegal menghimbau kepada masyarakat yang sedang diperantauan untuk tidak pulang kampung di lebaran tahun ini. Sebagai gantinya, Pemerintah Kota Tegal sudah mempersiapkan anggaran untuk kebencaan sebanyak Rp 2 miliar. Kedepannya dana ini digunakan untuk masyarakat miskin yang terkena dampak. Beliau juga menginstruksikan kepada Dinas Sosial Kota Tegal untuk secepatnya membantu masyarakat miskin, yang tidak mampu, atau yang membutuhkan ditengah pandemi ini. Disamping itu, para Aparatur Sipil Negara (ASN) beserta anggota DPRD Kota Tegal akan menghimpun dana sukarela untuk membantu masyarakat yang membutuhkan. (Dzulfaroh, 2020).

Selain Kota Tegal, Kota Tasikmalaya-pun melalui Wali Kota Budi Budiman membuat keputusan local lockdown setelah terjadinya lima kasus positif di daerahnya. Adapun diberlakukannya keputusan ini dimulai pada hari Selasa 31 Maret 2020. Dimana semua transportasi dilarang masuk ke Kota Tasikmalaya dan mengadakan pos penjagaan yang terdiri dari tim gabungan dari TNI, Polri, serta aparatur pemerintah daerah di setiap tempat yang memasuki kedalam kota. Masyarakat yang ingin masuk ke wilayah tanpa alasan jelas, maka tim yang berjaga akan menyuruh untuk berputar balik dan melarang masuk. (Dzulfaroh, 2020).

Selain itu Papua terlebih dahulu melakukan lockdown local atau karantina wilayah yang sudah melakukan penutupan pintu masuk utama, yakni Bandara Sentani yang ditutup pada hari Kamis 26 Maret 2020 sampai 9 April yang akan mendatang, terkecuali angkutan barang logistic dan pasien, keadaan darurat, sampel swab, itu mendapat kekhususan. Langkah ini diambil sebagai kesepakatan bersama antara Forkompinda Provinsi Papua dengan Bupati dan Wali Kota lingkup Papua. (Dzulfaroh, 2020).

Hal tersebut direspon presiden yang mengambil keputusan. Pertama, kebijakan lockdown di tingkat nasional ataupun di daerah merupakan kewenangan pemerintah pusat. Pemerintah Daerah tidak boleh melakukan kebijakan ini, karena pusat tidak ada arah 
kebijakan untuk melakukan lockdown, adapun yang perlu dilakukan ialah melalui penerapan pembatasan sosial (social distancing), melalui pembatasan aktivitas orang, menjaga jarak, dan tidak berkerumun untuk meminimalisir penyebaran virus ini. (Mensetneg, 2020). Namun demikian berdasarkan informasi yang didapat dari Kementerian Kesehatan Republik Indonesia penyebaran COVID-19 (corona virus) di Indonesia kian meningkat, seperti yang dijelaskan sebagai berikut :

\section{Grafik 1}

\section{Kasus COVID-19 di Indonesia}
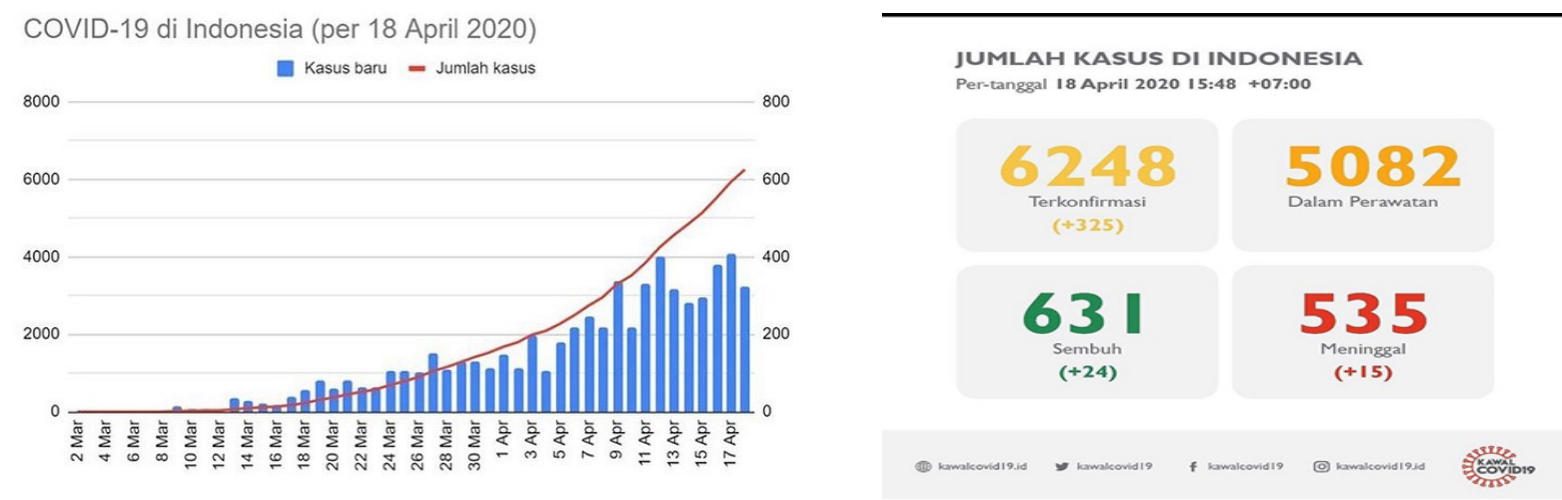

LAPORAN MEDIA HARIAN COVID19 TANGGAL 18 APRIL 2020 PUKUL 12.00 WIB

\begin{tabular}{|c|c|c|c|c|c|c|c|c|c|c|}
\hline \multirow{2}{*}{ No } & \multirow{2}{*}{ PROVINSI } & \multicolumn{3}{|c|}{$\begin{array}{l}\text { JUMLAH KASUS } \\
\text { TANGGAL } 18 \text { APRIL } 2020\end{array}$} & \multicolumn{3}{|c|}{$\begin{array}{l}\text { JUMLAH KASUS } \\
\text { DENGAN FOLLOWUP } \\
\text { SPESIMEN } 2 \times \text { NEGATIF }\end{array}$} & \multicolumn{3}{|c|}{$\begin{array}{l}\text { JUMLAH KASUS } \\
\text { MENINGGAL }\end{array}$} \\
\hline & & $\begin{array}{l}\text { S/D } 17 \\
\text { APRIL } \\
2020\end{array}$ & $\begin{array}{c}18 \\
\text { Apria } \\
2020\end{array}$ & KuM & $\begin{array}{l}\text { S/D } 17 \\
\text { ADPRIL } \\
2020\end{array}$ & $\begin{array}{l}18 \\
\text { Apria } \\
2020\end{array}$ & кUм & $\begin{array}{l}\text { SND 17 } \\
\text { APRIL } \\
2020\end{array}$ & $\begin{array}{c}18 \\
\text { Apria } \\
2020\end{array}$ & кUм \\
\hline 1 & ACEH & 5 & 1 & 6 & 4 & 0 & 4 & 1 & 0 & 1 \\
\hline 2 & BALI & 124 & 7 & 131 & 36 & 0 & 36 & 2 & 1 & 3 \\
\hline 3 & BANTEN & 311 & 10 & 321 & 9 & 0 & 9 & 34 & 0 & 34 \\
\hline 4 & Bangka Belitung & 6 & 0 & 6 & 0 & 0 & 0 & 1 & 0 & 1 \\
\hline 5 & Bengkulu & 4 & 0 & 4 & 0 & 0 & 0 & 1 & 0 & 1 \\
\hline 6 & DI YOGYAKARTA & 64 & 3 & 67 & 25 & 1 & 26 & 7 & 0 & 7 \\
\hline 7 & DKI JAKARTA & 2815 & 109 & 2924 & 204 & 1 & 205 & 246 & 7 & 253 \\
\hline 8 & JAMBI & 8 & 0 & 8 & 0 & 0 & 0 & 0 & 0 & 0 \\
\hline 9 & JAWA BARAT & 632 & 9 & 641 & 41 & 0 & 41 & 56 & 0 & 56 \\
\hline 10 & IAWA TENGAH & 304 & 25 & 329 & 36 & 8 & 44 & 41 & 0 & 41 \\
\hline 11 & $\begin{array}{l}\text { IAWA TIMUR } \\
\end{array}$ & 522 & 33 & 555 & 94 & 2 & 96 & 46 & 3 & 49 \\
\hline 12 & KALIMANTAN BARAT & 21 & 0 & 21 & 5 & 0 & 5 & 3 & 0 & 3 \\
\hline 13 & KALIMANTAN TIMUR & 44 & 10 & 54 & 10 & 1 & 11 & 1 & 0 & 1 \\
\hline 14 & KALIMANTAN TENGAH & 35 & 6 & 41 & 8 & 0 & 8 & $\frac{2}{2}$ & 0 & $\frac{2}{2}$ \\
\hline 15 & KALIMANTAN SELATAN & 74 & 18 & 92 & 6 & 0 & 6 & 6 & 0 & 6 \\
\hline 16 & KALIMANTAN UTARA & 47 & 3 & 50 & 2 & 0 & 2 & 1 & 0 & 1 \\
\hline 17 & KEPULAUAN RIAU & 58 & 21 & 79 & 5 & 1 & 6 & 7 & 0 & 7 \\
\hline 18 & NUSA TENGGARA BARAT & 51 & 4 & 55 & 2 & 0 & 2 & 2 & 0 & 2 \\
\hline 19 & SUMATERA SELATAN & 54 & 30 & 84 & 5 & 0 & 5 & $\frac{2}{2}$ & 0 & $\frac{2}{2}$ \\
\hline 20 & SUMATERA BARAT & 62 & 9 & 71 & 11 & 2 & 13 & 6 & 1 & 7 \\
\hline 21 & SULAWESI UTARA & 18 & 2 & 20 & 5 & 0 & 5 & 2 & 0 & 2 \\
\hline 22 & SUMATERA UTARA & 79 & 0 & 79 & 12 & 0 & 12 & 9 & 0 & 9 \\
\hline 23 & SULAWESI TENGGARA & 27 & 1 & 28 & 4 & 0 & 4 & 1 & 1 & 2 \\
\hline 24 & SULAWESI SELATAN & 332 & 11 & 343 & 43 & 0 & 43 & 23 & 2 & 25 \\
\hline 25 & SULAWESI TENGAH & 24 & 0 & 24 & 2 & 0 & 2 & 3 & 0 & 3 \\
\hline 26 & LAMPUNG & 26 & 0 & 26 & 10 & 0 & 10 & 5 & 0 & 5 \\
\hline 27 & RIAU & 26 & 4 & 30 & 9 & 0 & 9 & 4 & 0 & 4 \\
\hline 28 & MALUKU UTARA & 4 & 0 & 4 & 2 & 0 & 2 & 0 & 0 & 0 \\
\hline 29 & MALUKU & 14 & 3 & 17 & 1 & 5 & 6 & 0 & 0 & 0 \\
\hline 30 & PAPUA BARAT & 5 & 0 & 5 & 0 & 0 & 0 & 1 & 0 & 1 \\
\hline 31 & PAPUA & 89 & 6 & 95 & 15 & 3 & 18 & 6 & 0 & 6 \\
\hline 32 & SULAWESI BARAT & 7 & 0 & 7 & 1 & 0 & 1 & 1 & 0 & 1 \\
\hline 33 & NUSA TENGGARA TIMUR & 1 & 0 & 1 & 0 & 0 & 0 & 0 & 0 & 0 \\
\hline \multirow[t]{3}{*}{34} & GORONTALO & 4 & 0 & 4 & 0 & 0 & 0 & 0 & 0 & 0 \\
\hline & Dalam Proses Verifikasi & 26 & 0 & 26 & 0 & 0 & 0 & 0 & 0 & 0 \\
\hline & TOTAL & 5923 & 325 & 6248 & 607 & 24 & 631 & 520 & 15 & 535 \\
\hline
\end{tabular}

SUMBER DATA : KEMENTERIAN KESEHATAN RI

Pemerintah pusat melalui Menteri Kesehatan sudah menyetujui beberapa daerah untuk menerapkan Pembatasan Sosial Berskala Besar, adapun daerah-daerah yang dimaksud terdiri dari wilayah Jabodetabek yang terdiri 9 daerah di tiga Provinsi, yaitu DKI Jakarta, Jawa Barat, dan Banten. Kemudian, daerah lainnya yang mendapatkan izin adalah Kota Pekanbaru di Riau, Kota Makassar di Sulawesi Selatan, dan Kota Tegal di Jawa Tengah. Serta Jawa Barat yang 
menerapkan di wilayah Bandung Raya meliputi 5 daerah, yaitu Kota Bandung, Kabupaten Bandung, Kabupaten Bandung Barat, Kota Cimahi, dan Kabupaten Sumedang (Ramadhan, 2020).

\section{Aktor Kebijakan (Network Actors)}

a. Academician (Akademisi)

Unsur akademisi memiliki peran penting dalam suatu kebijakan, kaerena suatu kebijakan yang dibuat tentu harus secara ilmiah dapat diterima dan memberikan dampak yang nyata sebagai alternatif pemecahan masalah, beragamnya pendapat akademisi dari universitas yang tersebar di Indonesia terhadap kebijakan Pembatasan Sosial Berskala Besar (PSBB), seperti halnya dikatakan oleh Djohermansyah Djohan selaku Presiden Institut Otonomi Daerah menilai, kebijakan ini tidak efektif untuk mengatasi virus corana (COVID-19), dimana pemerintah pusat terkesan tidak menerima usulan yang disampaikan pemerintah daerah dalam mengatasi virus ini, maka untuk itu pemerintah pusat mesti mengkaji ulang kebijakan ini, karena dipandang kebijakan yang masih ragu-ragu. Karena dinilai kebijakan ini belum tegas dan keras, diterapkan pada keadaan masyarakat dengan tingkat disiplin yang rendah, seharusnya presiden memberikan kewenangan pemerintah daerah agar keleluasaan membuat kebijakan sesuai dengan keadaan daerah masing-masing. Ada beberapa usulan menarik dan ide-ide menarik dari pemerintah daerah yang justru ditolak pemerintah pusat, seperti halnya pemberlakuan jam malam yang merupakan ide bagus karena banyak orang berkumpul di warung kopi, di pasar malam yang tidak diketahui pejabat pemerintahan. Kedua, memberentikan bus antar provinsi merupakan ide bagus yang bertujuan mengurangi mobilitas orang banyak. Pemerintah tidak sekedar memberikan imbauan semata seperti tidak boleh pulang kampung atau mudik, tetapi harus memiliki arahan kebijakan yang jelas kepada pemerintah daerah sehingga mengantisipasi bertambahnya kasusu positif di tiap daerah. (Maharani, 2020).

Pendapat yang lain disampaikan oleh pakar kebijakan publik Universitas Trisakti Trubus Rahardiansyah, kebijakan PSBB sebetulnya merujuk pada UU No 6 Tahun 2018. Adapun kebijakan yang dikeluarkan kebijakan social distancing dan phisical distancing yang pada akhirnya tidak efektif karena dinilai kurang nya pendisiplinan secara nasional. Kebijakan PSBB ini disertai dengan kebijakan darurat sipil, hal ini menjadi kebingungan bagi masyarakat, karena darurat sipil ini berkaitan dengan bencana alam dan kerusuhan hal inilah yang secara penafsiran terjadi pro/kontra di masyarakat. PSBB ini harus dijabarkan secara utuh mulai dari waktu nya sampai kapan, lingkupnya seperti apa dan apa yg harus dilakukan ketika masyarakat tidak melakukan kebijakan itu, maka perlu dilakukan penjabaran melalui peraturan pemerintah yang jelas, selain itu harusnya dilakukan kebijakan kolaboratif, baik dari pemerintah pusat, pemerintah daerah, swasta dan masyrakat, pertama dengan meningkatkan koordinasi pusat dan daerah, kedua perlu pendekatan peran serta masyarakat bagaimana tokoh masyarakat ormas, $\mathrm{Rt} / \mathrm{Rw}$ dan organsisasi masyarakat lain ikut andil membantu kebijakan PSBB, dalam hal ini tidak hanya peran ekseskutif saja tetapi peran legisatif yakni DPR untuk mengawasi dan memberikan masukan ke pemerintah serta anggota DPR memantau sampai Dapilnya yang merupakan representatif wakil rakyat, karena tidak hanya eksekutif pun demikian legislatif harus ikut andil mengatasi masalah ini (Beritasatu, 2020).

Pengamat Kebijakan Publik Agus Pambagio mengatakan Pemerintah harus bersikap tegas dalam hal menangani wabah virus corona (COVID-19), mengingat imbauan social distancing belum banyak dipatuhi oleh masyarakat, karena pada dasarnya masyarakat Indonesia cenderung 'ngeyel' dan menyepelekan. (Zuhriyah, 2020). 
Peranan akademisi tentu berpengaruh besar pada kebijakan PSBB yang pemerintah hari ini coba terapkan untuk mengatasi masalah virus COVID-19 ini, kebijakan ini merupakan arahan dari Presiden kepada para pemimpin daerah baik di tingkat Provinsi, Kabupaten/Kota. Namun dirasa pemerintah terlambat merespon masalah ini sehingga kebingunan di tingkat daerah, maka tidak heran ketika beberapa daerah melakukan langkah inisiatif sendiri. Selain itu migrasi besar-besaran melalui pemudik yang pulang kampung yang justru rentan menyebarkan virus, maka disinilah akademisi memberi masukan pada pemerintah untuk mengambil keputusan yang tepat mengatasi hal tersebut, kebijakan PSBB bermakna konteks sosial artinya masyarakat masih bisa melakukan interaksi sosial tertentu untuk memenuhi kebutuhan yang mendesak, beda halnya jika diterapkan karantina wilayah atau karantina kesehatan, masyarakat pasti akan diam dirumah dan tidak ada interaksi sosial dengan catatan pemerintah baik pusat dan daerah memenuhi semua kebutuhan pokok mereka ketika dilakukan karantina.

\section{b. Business (Pengusaha)}

Unsur Penguasaha dan Penguasa merupakan hal yang tidak dipisahkan, tentu hal ini mempengaruhi suatu kebijakan, karena banyak pejabat pemerintah yang merangkap menjadi pengusaha, disisi lain tentu memiliki kepentigan masing-masing, seperti yang disampaikan Ekonom Senior mantan Menteri Perekonomian Dr. Rizal Ramli (ILC, 2020) dalam pembahasaan mengahadapi COVID-19, masih ada tenaga kerja asing (TKA) china masih bebas masuk ke indonesia, padahal virus corona berasal dari negar china. Mirisnya ada pejabat yang membela kedatangan TKA tersebut walaupun dilarang hal ini merupakan (bussines interest) kepentigan bisnis dari pejabat yang merangkap sebagai pengusaha. Oleh karena itu perlunya peran pengusaha yang tidak hanya mementingan kepentingan pribadi tetapi juga lebih mengedepankan kepentingan nasional.

Kebijakan pembatasan sosial berskala besar (PSBB) harus memperhatikankan sektor ekonomi masyarakat dan perusahaan. Tidak adanya skema jaminan sosial yang matang, maka memiliki potensi meningkatnya pengangguran dan masyarakat miskin. Aditya Mattoo Kepala Ekonom Bank Dunia untuk Asia Timur dan Pasifik mengatakan, kebijakan pembatasan akan sangat berdampak terhadap kondisi ekonomi masyarakat ataupun perusahaan. Apalagi, sebagian besar penduduk Indonesia bekerja di sektor informal dengan penghasilan harian. Maka yang diprioritaskan adalah meminimalisir dampak negatif terhadap usaha rumah tangga maupun dunia usaha lainnya. (Irawan, 2020).

Kebijakan ini menjadi dilema bagi para pengusaha yang dibayangi kerugian, karena banyak kegiatan usaha dan pekerjaan yang masih membutuhkan interaksi langsung antar manusia, tanpa adanya interaksi atau tidak berada di tempat tersebut, pekerjaan atau produktifitas tidak terjadi, hal tersebut akan berdampak penghasilan bagi perusahaan nantinya juga dinilai akan merosot (Anggraeni, 2020). Seperti usaha kecil menengah dan mikro (UMKM) yang terkena imbas selain kesulitan memasarkan produknya, bahkan ada yang berhenti berproduksi (kompas.com, n.d.)

Kalangkabutnya bagi sebagian perusahaan yang tetap melakukan kegiatan produksi, tanpa menghimbau aturan PSBB ini karena belum jelasnya secara teknis terhadap para pengusaha dalam mengatasi economic colaps atau kerugian yang amat besar, dampak nya masih ada perusahaan yang melakukan aktivitas kerjaseperti halnya yang disampaikan Serikat Pekerja Tekstil Sandang dan Kulit Serikat Pekerja Seluruh Indonesia (SP-TSK-SPSI) Kabupaten Sukabumi mengatakan kebijakan Pembatasan Sosial Berskala Besar (PSBB) berdampak pada aktivitas buruh yang mesti diliburkan di tengah pandemi COVID-19. Mochamad Popon selaku ketua menjelaskan, konsekuensi PSBB itu menyusul terbitnya Peraturan Pemerintah (PP) Nomor 21 Tahun 2020 tentang Pembatasan Sosial Berskala Besar 
serta Pasal 59 ayat (3) UU No. 6 Tahun 2018 yang sangat jelas menegaskan bahwa PSBB salah satu diantaranya peliburan tempat kerja namun terbalik ketika dilapangan, selain itu beberapa perusahaan yang sudah meliburkan karyawan pun, di luar yang berafiliasi dengan SP TSK SPSI, ada yang upahnya tidak dibayarkan, ada juga beberapa yang diganti dengan cuti tahunan hal itu sama artinya dengan tidak dibayarkan. Sehingga pekerja harus menggunakan mekanisme perundingan dengan pengusaha, dan sebagian besar pengusaha kebanyakan tidak mau membayar upah karyawan saat diliburkan kalau belum ada undang-undang yang mengaturnya secara jelas. Terkait hal tersebut, pemerintah perlu mengalokasikan anggaran baik dari APBN atau APBD dialokasikan untuk kompensasi bagi buruh saat diliburkan. Hal itu untuk mengantisipasi tidak maunya pengusaha membayar upah saat diliburkan karena dasar aturan yang belum mengatur secara jelas (Heryadie, 2020).

Maka dalam hal ini pengusaha tentu memberikan peranan penting dalam membantu menjalankan kebijakan ini ditingkat teknis dan sekaligus yang terkena dampak kebijakan ini, perlunya kolaborasi yang baik dibangun antar unsur aktor kebijakan ini, sehingga menghasilkan dampak baik pula terhadap pengusaha baik skala besar mapun skala kecil seperti sektor informal dan UMKM.

\section{c. Community (mayarakat)}

Masyarakat sebagai target group dari kebijakan ini, tentu adalah aktor yang memiliki pengaruh besar terhadap kebijakan ini, seperti yang dikatakan pakar kebijakan publik Universitas Trisakti Trubus Rahardiansyah, kebijakan PSBB ini tentu perlu melibatkan masyarkat melaui pendekatan peran serta masyarakat (PSM) bagaimana tokoh masyarakat, organisasi masyarakat (Ormas) dan organsisasi masyarakat lain bahkan tingkat $\mathrm{Rt} / \mathrm{Rw}$ ikut andil membantu kebijakan PSBB, sehingga tercapainya kesepahaman bersama dalam mekanai kebijakan ini(Beritasatu, 2020).

Namun permasalahan yang terjadi di masyarakat tidak semua orang bisa seutuhnya menarapkan kebijakan ini terutama bagi masyarakat kecil atau dengan ekonomi yang rendah, perlu untuk diperhatikan tidak hanya anjuran dan himbauauan yang ereka butuhkan tetapi wujud nyata empati yang dilakukan pemerintah ketika kebijakan ini diterapkan, seperti halnya membantu memenuhi kebutuhan pokok mereka, ketika hal ini tidak diperhatikan lebih maka konsekuensi yang jelas banyak masyarakat yang menganggur karena interaksi sosial dengan sekala besar yang benar benar dibatasi, sedangkan masayarakat perlu memenuhi kebutuhan hidupnya, maka tidak heran ketika banyak masyarakat yang masih keluar rumah mencari nafkah, hal ini tentu harus diperhatikan pemerintah baik pusat maupun daerah dalam membantu meringankan kebutuhan pokok masyarakat yang kebanyakan dari mereka adalah masyarakat kecil.

\section{d. Government (pemerintah)}

Sebagai aktor kebijakan yang memiliki ototritas dalam menentukan suatau kebijakan salahsatunya kebijakan PSBB seperti yang dikatakan Ketua Tim Gugus Tugas Penanganan COVID-19 Doni Monardo mengatakan, kebijakan Pembatasan Sosial Berskala Besar (PSBB) dikeluarkan agar tak ada beda pandangan antara pemerintah pusat dengan pemerintah daerah,dimana daerah dalam melakukan pembatasan sosial berskala besar tidak boleh bertentangan dengan kebijakan antar daerah yang lain dan kebijakan secara nasional. (Santoso \& Pramudita, 2020).

Kebijakan PSBB yang ditetapkan dalam PP No 21 Tahun 2020, setiap pemerintah daerah harus mendapat persetujuan pemerintah pusat. Hal ini sesuai Pasal 2 PP PSBB yang menyebutkan pemerintah daerah dapat melakukan PSBB atau pembatasan kegiatan/pergerakan 
orang/barang dalam satu Provinsi atau Kabupaten/Kota tertentu dengan persetujuan Menteri Kesehatan. Dalam Pasal 5 ayat (1) PP 21/2020 menyebutkan,

"Dalam hal Pembatasan Sosial Berskala Besar telah ditetapkan oleh menteri yang menyelenggarakan urusan pemerintahan di bidang kesehatan, Pemerintah Daerah wajib melaksanakan dan memperhatikan ketentuan sebagaimana diatur dalam UU Nomor 6 Tahun 2018 tentang Kekarantinaan Kesehatan. Selain itu Pasal 5 PP 21/2020 itu amanat Pasal 49 ayat (3) UU Kekarantinaan Kesehatan yang menyebutkan, "Karantina Wilayah dan Pembatasan Sosial Berskala Besar sebagaimana dimaksud pada ayat (1) ditetapkan oleh Menteri.

Pemerintah tentu perlu mempertimbangkan dengan baik terhadap kebijakan PSBB ini yang dipilih sebagai alternatif kebijakan untuk mengatasi penyebaran COVID-19 yang kian meningkat di Indonesia, namun pemerintah pun tidak boleh menutup telinga ketika mendapat masukan buttom-up atau kritik terhadap kebijakan yang coba diterapkan ini, yang semata mata untuk mempertegas arah kebijakan ini agar tepat sasaran dan berdampak baik terhadap berbagai sektor baik sosial, ekonomi, kesehatan dan lain sebagainya.

Pemerintah Daerah DKI Jakarta mengatakan bahwa kebijakan pembatasan sosial berskala besar (PSBB) di Jakarta mulai berlaku Jumat 10 April 2020 sampai Kamis 23 April 2020. Untuk melaksanakan kebijakan ini, Pemerintah Provinsi DKI Jakarta mengeluarkan Peraturan Gubernur Nomor 33 Tahun 2020 tentang Pelaksanaan Pembatasan Sosial Berskala Besar yang terdiri dari 28 pasal untuk mengatur Ibu Kota baik kegiatan perekonomian, kegiatan sosial, kegiatan budaya, kegiatan keagamaan, dan pendidikan. Anies Baswedan selaku Gubernur menegaskan bahwa selama masa pemberlakuan kebijakan ini, semua warga Jakarta baik pemerintah maupun masyarakat harus menaati semua ketentuan yang ditetapkan (Carina, 2020). Selain itu langkah yang dilakukan Pemerintah DKI Jakarta adalah 1,25 juta kepala keluarga (KK) di Jakarta akan menmperoleh bantuan sembako bagi warganya yang terdampak COVID-19. Bantuan ini merupakan kewajiban pemerintah selama masa penerapan PSBB, karena itu, Pemerintah Provinsi DKI Jakarta dengan pemerintah pusat bersama-sama mengatur pendistribusian bantuan tersebut (Nursita, 2020).

Setelah disetujui pengajuan lima daerah di Jawa Barat menerapkan Pembatasan Sosial Berskala Besar (PSBB) melalui Peraturan Gubernur Jawa Barat Nomor 27 Tahun 2020 Tentang Pedoman Pembatasan Sosial Berskala Besar Dalam Penanganan Corona Virus Disease 2019 (COVID-19) Di Daerah Kabupaten Bogor, Daerah Kota Bogor, Daerah Kota Depok, Daerah Kabupaten Bekasi, Dan Daerah Kota Bekasi, yang akan digelar di hari Rabu 15 April 2020. Pelaksaannya akan dilakukan selama 14 hari ke depan. Kelima wilayah tersebut adalah Kota Depok, Kota Bogor, Kabupaten Bogor, Kabupaten Bekasi, dan Kota Bekasi. Selama pelaksaan PSBB nanti, pihaknya akan melakukan masif tes dengan target tes sebanyak 300 ribu orang. Sementara itu, terkait bantuan selama PSBB diberlakukan, Emil mengatakan dibagi menjadi dua golongan yang menerima bantuan, diantaranya, golongan pertama merupakan yang terdata oleh pemerintah atau tersurvei DPKS, mereka mayoirtas akan dibantu dengan APBN. Yang golongan dua, mereka yang rawan miskin baru yang sebelumnya tidak masuk daftar bantuan (okenews, 2020), selain itu PSBB Bandung Raya dimulai diberlakukan pada hari Rabu 22 April 2020 pukul 00.00 WIB selama 14 hari yang meliputi Kota Bandung, 
Kabupaten Bandung, Kabupaten Bandung Barat, Kabupaten Sumedang, dan Kota Cimahi. Dengan populasi 9,4 juta penduduk, Bandung Raya adalah kawasan metropolitan dengan penduduk terbesar ketiga di Indonesia setelah Jabodetabek dan Gerbangkertosusila di Jawa Timur (voaindonesia.com, 2020).

Daerah lain yang memberlakukan PSBB adalah Provinsi Banten. Wahidin Halim selaku Gubernur telah memberlakukan kebijakan ini di wilayah Tangerang Raya yang meliputi Kota Tangerang, Kabupaten Tangerang dan Kota Tangerang Selatan mulai Sabtu, 18 April 2020 sampai Minggu, 03 Mei 2020. Kebijakan ini diatur dalam Peraturan Gubernur Banten Nomor 16 Tahun 2020 tentang Pedoman Pelaksanaan Pembatasan Sosial Berskala Besar Dalam Penanganan Corona Virus Disease 2019 (COVID-19) Di Kabupaten Tangerang, Kota Tangerang dan Kota Tangerang Selatan. Adapun aturan ini melingkupi pelaksanaan PSBB; hak, kewajiban serta pemenuhan kebutuhan dasar penduduk selama PSBB; sumber daya penanganan Corona Virus Disease (COVID-19), pemantauan, evaluasi, dan pelaporan; dan sanksi pelanggar PSBB, sedangkan untuk koordinasi, pengerahan sumber daya dan operasional pelaksanaan PSBB diatur oleh Bupati/Walikota (Metrotempo.co, 2020).

\section{e. Media (Media Massa)}

Media mempengaruhi kebijakan yang dibuat pemerintah karena memiliki peran utama sebagai penghubung pemerintah dengan masyarkat melalui gerbang informasi agar menyampaikan informasi yang tepat dan medepankan fakta di tengah pandemi ini dan menangkal media hoax yang memuncu munculnya kebingungan dan pemahaman yang salah terhadap masyarakat dalam memahami dan menyikapi virus ini (Putri, 2020). Selain memberikan informasi tentang bahayanya virus ini juga memberikan pemahaman dalam merubah cara pandang masyarakat menghadapi virus ini sehingga tidak muncul diskriminatif terhadap korban yang terkena COVID-19. Tentu harus seimbang dengan informasi yang diberikan kepada masyarakat untuk menguatkan dari psikis masyarakat, sehingga tidak terjadi diskriminasi dari masyarakat terhadap korban yang terkena virus ini yang diperlakukan tidak adil secara sosial, seperti halnya korban yang meninggal akibat virus ini yang ditolak oleh masyarakat di berbagai daerah (Kurniati, 2020). Dalam hal kebijakan PSBB ini peran media selain pendukung terhadap kebijakan yang dibuat pemerintah, juga mendukung informasi yang dibutuhkan masyarakat terhadap perkembangan COVID-19 ini, seta media mesti lebih memberikan tayangan yang memiliki unsur pendidikan, saat dimana sekolah tutup dan anakanak belajar dari rumah (Erina, 2020).

Berdasarkan pemaparan diatas, maka bisa diperoleh hasil dari jurnal ini yaitu mengetahui begitu besarnya peran aktor yang terlibat dalam kebijakan Pemabatasan Sosial Berskala Besar (PSBB) dalam memutus rantai penyebaran COVID-19 di Indonesia, kebijakan ini bisa berjaan baik ketika terbangun kolaborasi 5 (Lima Unsur) unsur subjek atau stakeholder, yaitu: Academician (Akademisi), Business (Pengusaha), Community (mayarakat), Government (pemerintah) dan Media (Media Massa). Adapun langkah yang dilakukan pemerintah baik Pusat, Provinsi dan Daerah Kabupaten/Kota, dalam menyikapi masalah COVID-19 membuat alternatif untuk meringankan beban masyarakat dengan membantu memenuhi kebutuhan pokok/dasar masyarakat yang terkena dampak COVID-19 selama kebijakan PSBB ini diterapkan. 


\section{Simpulan}

Kolaborasi 5 unsur subjek atau stakeholder, yaitu: Academician (Akademisi), Business (Pengusaha), Community (mayarakat), Government (pemerintah) dan Media (Media Massa) memberikan pengaruh besar terhadap kebijakn pembatasan sosial berskal besar (PSBB), tentu banyak hal yang harus dipertimbangkan dalam menerapkan kebijakan ini, melalui peran akademisi yang membantu pemerintah meberikan masukan dan solusi secara ilmiah untuk besama menagatasi permasalahan COVID-19, pengusaha adalah aktor yang ikut andil terhadap kebijakan ini mereka selain sebagai aktor juga sebagai eksekutor karena berperan langsung secara teknis di lapangan yang melibatkan banyak masyarakat dalam hal ini sebagai buruh dan pegawai dalam perusahaan yang terkena imbas besar dari COVID 19, masyarakat yang menjadi target group perlu diikutsertakan sebagai aktor kebijakan melalui peran serta masyarakat melalui peragkat dan lembaga yang ada dimasyarakat, pemerintah sebagai pemangku kebijakan perlu membangun koordinasi pusat dan daerah, sehingga terciptanya keserasian dan satu arah kebijakan yang jelas serta melakukan monitoring terhadap kebijakan PSBB secara bertahap untuk memudahkan menganalisis kendala yang ditemui seiring diterapkannya kebijakan tersebut, dan media sebagai jembatan penghubung antar aktor tentu meberikan informasi yang valid dan faktual serta memberikan pendidikan terutama bagi masyarakat umum untuk merubah cara pandang terhadap virus ini agar tidak memicu diskriminatif social serta menangkal medi hoax yang meresahkan masyarakat.

\section{Referensi}

Kiky, A. (2020). Manajemen Risiko Terhadap Black Swan Eventmaret 2020 Di Indonesia. Studi Kasus Efek Covid-19 Terhadap Pasar Modal Indonesia. Jurnal Bina Manajemen (Jbm), 1-16.

Ramadhan, A. (2020). Pemerintah Setujui PSBB Di 17 Daerah, Ini Rangkuman Sejumlah Wilayah. Kompas.Com.

Ayu, L., Ratriani. (2020, March 18). Berikut Daftar 8 Negara Yang Sudah Tetapkan Lockdown Akibat Virus Corona. Kompas.Com. Https:/Www.Kompas.Com/Tren/Read/2020/03/18/195000965/Berikut-Daftar-8Negara-Yang-Sudah-Tetapkan-Lockdown-Akibat-Virus-Corona

Beritasatu. (2020). Dialog: Pembatasan Sosial Skala Besar. Https://Www.Youtube.Com/Watch?V=Pvny0i36-Pe

Carina, T. (2020). Berlaku 14 Hari, Penerapan Psbb Di Jakarta Sampai 23 April 2020. Kompas.Com.

Telaumbanua, D. (2020). Urgensi Pembentukan Aturan Terkait Pencegahan COVID-19 Di Indonesia. Jurnal Qalamuna -Jurnal Pendidikan, Sosial, Dan Agama, 12, 59-70.

Damarjati, D. (2020, April 5). Data Corona Terkait Indonesia, 5 April 2020 Pukul 16.30 Wib. Detiknews. Https:/News.Detik.Com/Berita/D-4965981/Data-Corona-Terkait-Indonesia5-April-2020-Pukul-1630-Wib

Heryadie, H. (2020, April 6). Konsekuensi PSBB Buat Buruh, SPSI Sukabumi: Jangan Jadi Ajang PHK Diam-Diam! Sukabunmiupdate.Com. Https://Sukabumiupdate.Com/Detail/Sukabumi/Ekonomi-Dan-Bisnis/67312Konsekuensi-Psbb-Buat-Buruh-Spsi-Sukabumi-Jangan-Jadi-Ajang-Phk-Diam-Diam 
ILC. (2020). Tajam! Kritik Keras Rizal Ramli Kepada Presiden Jokowi Dalam Menghadapi Covid-19. Tv One. Https://Www.Youtube.Com/Watch?V=Xddu971-5gc

Indriya. (2020). Konsep Tafakkur Dalam Alquran Dalam Menyikapi Coronavirus Covid-19. Jurnal Sosial \& Budaya Syar'i, 7, 211-216. Https://Doi.Org/10.15408/Sjsbs.V7i3.15050

Irawan, K.I. (2020). Tekan Dampak Sosial Pembatasan. Kompas.Com. Https://Bebas.Kompas.Id/Baca/Bebas-Akses/2020/04/01/Tekan-Dampak-SosialPembatasan/

Kompas.Com. (N.D.). Topang Ekonomi, DPR Minta Pemerintah Prioritaskan UMKM Artikel Ini Telah Tayang Di Kompas.Com Dengan Judul Topang Ekonomi, Dpr Minta Pemerintah Prioritaskan Umkm. Kompas.Com.

Maharani, T. (2020). Pengamat: Kebijakan Psbb Belum Tegas, Tak Efektif Atasi COVID-19. Kompas.Com. Https:/Nasional.Kompas.Com/Read/2020/04/04/15202701/PengamatKebijakan-Psbb-Belum-Tegas-Tak-Efektif-Atasi-Covid-19.

Mensetneg, H. (2020). Arahan Presiden Terkait Kebijakan Pemerintah Pusat Dan Daerah Tangani COVID-19.

Metrotempo.Co. (2020). Gubernur Banten: PSBB Tangerang Raya Berlaku Hingga 3 Mei 2020. Metrotempo.Co. Metrotempo.Co

Parwanto, M. (2020). Virus Corona (2019-Nov) Penyebab Covid-19. Jurnal Biomedika Dan Kesehatan, 3, 1-2.

Nursita. (2020). Anies: 1,25 Juta Keluarga Akan Dapat Bantuan Sembako Tiap Pekan. Kompas.Com. Https://Megapolitan.Kompas.Com/Read/2020/04/09/23164321/Anies125-Juta-Keluarga-Akan-Dapat-Bantuan-Sembako-Tiap-Pekan.

Okenews. (2020). Begini Penerapan Psbb 5 Wilayah Di Jawa Barat. Okenews. Https://News.Okezone.Com/Read/2020/04/12/525/2197999/Begini-Penerapan-Psbb-5Wilayah-Di-Jawa-Barat

Redaksi We Online. (2020, March 12). 5 Negara Ini Paling Parah Terdampak Virus Corona, Indonesia Aman Terkendali. Wartaekonomi.Go.Id. Https:/Www.Wartaekonomi.Co.Id/Read276158/5-Negara-Ini-Paling-Parah-TerdampakVirus-Corona-Indonesia-Aman-Terkendali/2

Dewi, R.K. (2020, March 20). Virus Corona, Korea Selatan Dan Klaim Penurunan Kasus COVID-19.

Kompas.Com. Https://Www.Kompas.Com/Tren/Read/2020/03/20/172000265/Virus-Corona-KoreaSelatan-Dan-Klaim-Penurunan-Kasus-Covid-19-?Page=3

Arum, R. (2020). Pembatasan Sosial Di Indonesia Akibat Virus Corona Ditinjau Dari Sudut Pandang Politik.

Rolanda, K., \& Markusb, M. (2020). COVID-19 Pandemic: Palliative Care For Elderly And Frail Patients At Home And In Residential And Nursing Homes. Swiss Medical Weekly, $1-2$.

Santoso, B., \& Pramudita, Y. A. (2020, April 6). Penjelasan Gugus Tugas Covid-19 Terkait Kebijakan PSBB.

Suara.Com. Https://Www.Suara.Com/News/2020/04/06/144738/Penjelasan-Gugus-Tugas-Covid-19Terkait-Kebijakan-Psbb 
Tian,S., Hu, W., Niu, L., Liu, Xu, H. (2020). Pulmonary Pathology Of Early Phase 2019 Novel Coronavirus (COVID-19) Pneumonia In Two Patients With Lung Cancer. Journal Of Thoracic Oncology. Https://Doi.Org/Https://Doi.Org/10.1016/J.Jtho.2020.02.010.

Syamsir, A., Nur, M. I., Wahidah, I., \& Alia, S. (2019). Kualitas Pelayanan Publik Dalam Pembelajaran Berbasis Daring Di Tengah Pandemi Coronavirus Disease 2019. Digital Library Uin Sunan Gunung Djati, 1-12. Http://Digilib.Uinsgd.Ac.Id/30678/1/Kualitas Pelayanan Publik Dalam Pembelajaran Berbasis Daring Di Tengah Pandemi Coronavirus Disease 2019.Pdf

Zulva, TN.I. (2020). COVID-19 Dan Kecenderungan Psikosomatis. Fakultas Psikologi Dan Kesehatan Uin Walisongo Semarang.

Yuniningsih, T., Titi Darmi, S. S. (2019). Model Pentahelik Dalam Pengembangan Pariwisata Di Kota Semarang. Journal Of Public Sector Innovation, 3, 84-93.

Voaindonesia.Com. (2020). Bandung Raya Terapkan PSBB Mulai 22 April. Voaindonesia.Com. Https://Www.Voaindonesia.Com/A/Bandung-Raya-Mulai-Psbb-22April/5377662.Html

Yunus, N. R., \& Annissa, R. (2020). Kebijakan Pemberlakuan Lockdown Sebagai Antisipasi Penyebaran Corona Virus Covid-19. Jurnal Sosial Dan Budaya Syar'i, 7, 227-238. Https://Doi.Org/10.15408/Sjsbs.V7i3.15083 